DOI: 10.32844/2222-5374-2020-104-2.65

УДК: 347.965(477)

Северінова О. Б.,

кандидат політичних наук, доцент

Донецький юридичний інститут МВС України

\title{
ВІЙСЬКОВО-ПОЛІТИЧНА РОБОТА З КАДРАМИ ЗБРОЙНИХ СИЛ УРСР У ПЕРЕДВОЄННИЙ ПЕРІОД
}

Стаття присвячена дослідженню особливостей військово-політична робота з кадрами збройних сил УРСР у передвоєнний період. Також в статті проаналізовано основні напрямки та підходи різних вчених щодо вивчення вказаної проблематики. З'ясовано, що для розробки організаційної структури і штатів центральних органів Наркомату оборони СРСР, на підставі затвердженої наркомом оборони схеми, були створені групи по п'ять осіб, яким доручили подати пропозищї щодо реформування штатів і організації управлінь. Для роботи над перетворенням Політичного управління Робітничо-Селянської Червоної Армії була призначена група на чолі з заступником начальника. Після закінчення роботи цієї групи політичне керівництво отримало пропозиції про вдосконалення системи управління пропаганда і оптимізації ряду штатних категорій. З'ясовано, що збільшення чисельності армії знову призвело до браку політпрацівників, послабило політроботу, особливо серед рядового і молодшого начальницького складу, змусило керівництво країни робити нові організаційні перетворення в цілях подолання загрози, ослаблення керівництва Збройними Силами, зниження впливу партії в них. До того ж, у зв'язку з швидким розгортанням Збройних Сил, репресіями в армії велике число молодих командирів, часто не мали достатнього досвіду керівництва військами, висувалися на вищі посади. Багато з них були безпартійними. Таким чином, більшість командного складу вже в 1933 р було досить молодими військовослужбовцями, які не нагромадили необхідного досвіду військового керівництва. Ситуація була серйозно посилена в середині - другій половині 30-х років. Визначено, що слабка підготовка офіцерських кадрів була обумовлена, перш за все, недостатнім рівнем знань, отриманих в ході навчання в військово-навчальних закладах. Умови діяльності військово-навчальних закладів того періоду були надзвичайно складними. Навчальні програми у військових академіях і училищах часто складалися некомпетентними людьми. Військово-політичні навчальні заклади складали за чисельністю майже 20\% всіх сухопутних військ. Поряд з розширенням старих і створенням нових середніх і вищих військово-навчальних закладів, утворюється широка мережа курсів перепідготовки. Крім раніше існуючих двох курсів з удосконалення політскладу, відкриваються нові курси для підготовки комісарів.

Ключові слова: Збройні сили, військово-службові відносини, кадри, військово-політична робота. 
У червні 1934 р Реввійскрада СРСР, що існувала як колегіальний орган керівництва Збройними Силами, був скасований. Цією ж постановою ЦВК СРСР Народний комісаріат з військових і морських справ був перейменований в Народний комісаріат оборони СРСР. Народним комісаром оборони був затверджений К.Є. Ворошилов, його першим заступником - Я.Б. Гамарник, другим - М.Н. Тухачевський. У листопаді при Народному комісаріаті оборони СРСР був створений Військовий рада, який виконував функції дорадчого органу, до його складу входило 80 чоловік. Одночасно були ліквідовані військові ради в округах і арміях. Військова рада Наркомату оборони СРСР як дорадчий орган, припинив свою діяльність в березні 1938 р з установою Головної військової ради, а пізніше цей орган і зовсім був ліквідований.

Для розробки організаційної структури і штатів центральних органів Наркомату оборони СРСР, на підставі затвердженої наркомом оборони схеми, були створені групи по п’ять осіб, яким доручили подати пропозиції щодо реформування штатів і організації управлінь. Для роботи над перетворенням Політичного управління Робітничо-Селянської Червоної Армії (ПУРСЧА) була призначена група на чолі з заступником начальника ПУРСЧА А.С. Булинь. Після закінчення роботи цієї групи політичне керівництво отримало пропозиції про вдосконалення системи управління пропаганда і оптимізації ряду штатних категорій.

У вересні 1935 року були введені військові звання для керівного складу Збройних Сил. Для військово-політичного складу встановлювалися наступні звання: політрук, старший політрук, батальйонний комісар, полковий комісар, корпусний комісар, армійський комісар. 2 рангу, армійський комісар 1 рангу. Звання армійського комісара 1-го рангу отримав лише одна людина - начальник Політичного управління РСЧА Я.Б. Гамарник, а ще п'ятнадцяти, в основному начальникам політуправління округів і флотів, було присвоєно звання армійського комісара 2-го рангу.

Величезна робота проводилася щодо підвищення ідейного рівня всіх армійських комуністів. Для цього було введено так зване політичне просвітництво, мережа гуртків якого безперервно зростала. У 1930 р в них займалися 264 тис. чоловік, в 1931 - 313 тис. чоловік, а 1932 року - вже 400 тис. військовослужбовців. Гуртки партійної освіти (партпроса) користувалися великою популярністю у всього особового складу. Разом з комуністами в гуртках займалася безпартійні командири і червоноармійці. У 1932 р безпартійні становили більше однієї третини всіх слухачів гуртків партійної освіти.

Організаційно-ідеологічні перетворення політичних органів адекватно викликали загальне піднесення рівня партійно-політичної роботи 3 усім особовим складом армії і флоту.

Наростання загрози військового нападу на Радянський Союз змусило військово-політичне керівництво країни до збільшення Збройних Сил. Тільки за чотири роки, починаючи з 1937 р, чисельність армії зросла майже в три рази і склала більше 5 млн. Чоловік. Нарешті довелося відмовитися від територіально-міліційних системи комплектування Збройних Сил та цілком перейти на кадрову основу.

Збільшення чисельності армії знову призвело до браку політпрацівників, послабило політроботу, особливо серед рядового і молодшого 
начальницького складу, змусило керівництво країни робити нові організаційні перетворення в цілях подолання загрози, ослаблення керівництва Збройними Силами, зниження впливу партії в них. До того ж, у зв'язку з швидким розгортанням Збройних Сил, репресіями в армії велике число молодих командирів, часто не мали достатнього досвіду керівництва військами, висувалися на вищі посади. Багато з них були безпартійними.

Таким чином, більшість командного складу вже в 1933 р було досить молодими військовослужбовцями, які не нагромадили необхідного досвіду військового керівництва. Ситуація була серйозно посилена в середині - другій половині 30-х років.

Одним із найсерйозніших чинників, що призвели до зниження бойової готовності і великий брак як командного, так і політичного складу, стали репресії, різко посилилися в 1934 р після вбивства С.М. Кірова.

До 1937 р репресії, особливо проти партійних і політичних працівників набули масового характеру. На лютнево-березневому Пленумі ЦК ВКП (б) від 1937 р І.В. Сталін, щоб виправдати незаконні дії, нав'язав установку, що необхідно викрити політичних «дворушник» і «ворогів народу», вказав на те, що допущено запізнення на кілька років в їх знищенні. Нарком внутрішніх справ В.Д. Єжов зазначив, що за наміром ворога «повалення сталінського режиму ... може статися ... в результаті палацового ... або військового перевороту, що може досконалим одним з червоних генералів» $[1$, с. 6]

14 червня 1937 р. був опублікований звернений до всього особового складу Червоної Армії наказ наркома оборони СРСР № 96 від 12 червня 1937 р., в якому вказувалося, що з 1 по 4 червня 1937 р. в присутності членів уряду відбувся Військова рада при наркома оборони СРСР. На засіданні було заслухано доповідь К.Є. Ворошилова про нібито розкритою наркоматом внутрішніх справ СРСР «зрадницької контрреволюційній військовій фашистської організації», яка нібито, була «строго законспірованої, довгий час існувала і проводила підлу підривну, шкідницьку і шпигунську роботу в Червоній Армї̈» [2, с. 2].

Створення атмосфери «класової» нетерпимості і загальної підозрілості передувало розгортання репресій проти командного і політичного складу РСЧА. У цій ситуації основне призначення політпрацівників стало зводитися до тотального контролю над політичною діяльністю, а вже потім до виховання.

28 листопада 1938 р виступаючи на засіданні Військової ради, К.Є. Ворошилов повідомив: «Ви знаєте, що собою являла чистка рядів РСЧА. Я не стану тут опубліковувати докладні числа. Вони досить значні. Частка була проведена, радикальна і всебічна ... Досить сказати, що за весь час ми вичистили понад чотири десятки тисяч людей».

Виступаючи на XVIII з'їзді ВКП (б), начальник Політичного управління РСЧА Л.З. Мехліс з питання про «військовій змові», заявив: «Ніщо не повинно вислизнути від пильного, більшовицького очі комісарів. Вони повинні знати все, що робиться в кожному куточку Червоної Армї̈, бути вірним провідником генеральної лінії Сталінського Центрального Комітету і разом $з$ парторганізаціями в корені припиняти можливу зраду, оберігати нашу улюблену армію від шпигунів, стежити, щоб жоден ворог не проник в наші ряди» [3, с. 274]. 
Природно, що політоргани так само зазнали чищенні. Були знищені всі перші армійські комісари, не витримавши очікування арешту, наклав на себе руки начальник ПУРСЧА Я.Б. Гамарник. За один тільки рік (1937) з армії було звільнено 1469 політпрацівників, в тому числі з політичних мотивів посилання - 1045 осіб; з них членів військових рад, начальників політуправління військових округів та їх заступників - 18, воєнкомів корпусів - 16, воєнкомів дивізій - 57, воєнкомів училищ і морських з'єднань - 33 людини. До початку 1938 р некомплект політпрацівників склав 27\% загальної їх потреби (10 341 осіб), а некомплект вищого політскладу становив 938 осіб [4, с. 23]

Знищення військової еліти перед війною оцінювалося К.Є. Ворошиловим, його сподвижниками, як фактор значного посилення РСЧА. Виступаючи 4 червня 1937 року на нараді командно-начальницького складу, присвяченому «військової змови», нарком оборони заявив: «... ми сміливо можемо сказати сьогодні народу, очищаючись від усякої гидоти, від всяких негідників, шпигунів ми поведемо армію до перемоги. .. противник не посміє ворухнути своїми військами ..., противник злякається, після втрати своєї агентури ..., противник буде більше боятися нашої армії».

У своєму виступі на Військовій раді наркомату оборони СРСР за підсумками бойової та політичної підготовки за 1938 р. начальник Політичного управління Л.3. Мехліс про стан політорганов говорив: «До початку 1938 р РСЧА був некомплект в політскладу близько 12000 чоловік. За 9 місяців 1938 р звільнено 2340 осіб, але ця кількість збільшується в зв'язку з відкриттям 16 окружних політучилище, куди будуть послані 12000 грамотних політруків з утворенням 6-7 класів» [5, с. 190].

У 1938 р звільнено з армії 3176 політпрацівників: а) у зв'язку з арештом - 265 чол. б) виключених з ВКП (б) - 982 чол. в) учасників антипартійних угруповань - 187 чол. г) за директивою наркома оборони від 21 червня 1938 року (поляки, німці, латиші, литовці, естонці, китайці та ін.) - 363 чол. д) за вироком суду, службовою невідповідністю, невиправних пияків, морально розклалися - 879 чол. [5, с. 193].

У роботі з очищення кадрів політскладу (звільнення з армії, виключення з партії) мали місце грубі помилки і перегини, головним чином в результаті некритичного ставлення Військових Рад і Політуправління Червоної Армії до матеріалів особливих відділів.

В порядку виправлення допущених при звільненні політпрацівників помилок ПУРСЧА повернуло в армію в 1939 і 1940 роках 386 чоловік [5, c. 193].

Положення, що створилося в політорганам і партійних організаціях, стан партійно-політичного керівництва стало предметом обговорення на нараді керівного складу Червоної Армії, скликаного ЦК ВКП (б) на початку травня 1937 г. На нараді було висловлено пропозицію, знову ввести в ланці округ, армія військові ради , різко розсунути рамки інституту військових комісарів, ввести його в усіх корпусах, дивізіях, бригадах, а в ротах інститут політруків. Це, на думку учасників наради, дало можливість посилити партійно-політичну роботу i, перш за все, зміцнити партійні та політичні органи і організації. Обговоривши пропозицію учасників наради, ЦК ВКП (б) 8 травня 1937 р визнав за необхідне створити в військових округах і 
арміях поради в складі трьох осіб (командувача військами округу, армії і двох членів військової ради).

Планувалося ввести у всіх військових частинах, з'єднаннях, штабах, управліннях, установах Наркомату оборони СРСР інститут військових комісарів, а в ротах і їм рівним підрозділам - політруков. Одночасно Наркомату оборони доручалося розробити та подати Положення про військові комісарів. 7 червня 1937 року наказом Наркома оборони командири-комісари були звільнені від функцій комісарів, а їх помічники по політичній частині були призначені військовими комісарами [6, с. 238].

Головним напрямком у діяльності військових комісарів було керівництво політичною роботою. У Положенні про військові комісарів, затвердженому ЦК ВКП (б) 10 серпня 1937 р. говорилося: «Для політичного керівництва і безпосереднього проведення партійно-політичної роботи у військових частинах, з'єднаннях, навчальних закладах, установах та управліннях РСЧА Народним комісаром оборони СРСР, за поданням політичного управління РСЧА, призначаються військові комісари» [7, с. 29].

По суті, вводилася неповна форма єдиноначальності. Відбувся розподіл керівництва на військове і політичне (командир керував військовою стороною життєдіяльності частини, а комісар політичної).

Введення інституту військових комісарів було надзвичайним заходом, викликаної конкретною історичною обстановкою. 12 серпня 1940 року Указом Президії Верховної Ради СРСР «Про зміцнення єдиноначальності в Червоній Армії і Військово-Морських Силах» в армії знову вводиться єдиноначальність. У ньому йшлося про те, що, оскільки інститут військових комісарів виконав свої завдання, а командні кадри за останні роки серйозно зміцніли, з метою повного здійснення єдиноначальності скасовується інститут військових комісарів і вводиться інститут заступників командирів по політичній частині. Командир ставав повновладним керівником військ, ніс повну відповідальність і за політроботу в частинах [8, с. 289]. Ухвалення останнього документа було викликане, перш за все, осмисленням недоліків військового будівництва в світлі підсумків радянсько-фінляндської війни. У політдонесень ПУРСЧА часто зустрічалися висловлювання про правильність введення єдиноначальності. Так, наприклад в політдонесень № 0942 від 23 серпня 1940 р. говорилося: «Бійці, командири і політпрацівники з великим піднесенням зустріли Указ Президії Верховної Ради СРСР і наказ наркома, як захід, спрямований на підвищення бойової потужності могутності Червоної Армії, на зміцнення радянської військової дисципліни».

До 1937 р питома вага молодих командних кадрів в частинах і з'єднаннях становив в: стрілецьких - 60\%; танкових - 45\%; авіаційних - 25\%; а в окремих ланках командного складу це оновлення було ще більшим [9, с. 100].

У 1938 р ЦК ВКП (б) для збільшення кількості політпрацівників вирішив залучити до політроботі найбільш перевірених і політично грамотних комсомольців в якості заступників і помічників політичних керівників. Нарком оборони К.Є. Ворошилов про даний захід говорив: «Партійні організації, воєнкоми частин ... повинні вважати своїм основним завданням підготувати комсомольців, призначених заступниками або помічниками 
політруків, щоб вони останнім часом стали повноцінними политработниками сталінської закалки» [7, с. 31]. Але дане збільшення числа політпрацівників не змогло докорінно змінити ситуацію, що склалася.

Кількість командного складу збільшувалася, а якість його підготовки залишалося невисоким. Станом на 1 січня 1941 р. спискова чисельність командно-начальницького складу армії і флоту становила 579581 осіб, з яких 7,1\% мали вищу, 55,9\% середнє, 24,6\% - прискорене військову освіту і $12,4 \%$ взагалі не мали військової освіти [10, с. 28].

Слабка підготовка офіцерських кадрів була обумовлена, перш за все, недостатнім рівнем знань, отриманих в ході навчання в військово-навчальних закладах. Умови діяльності військово-навчальних закладів того періоду були надзвичайно складними. Навчальні програми у військових академіях і училищах часто складалися некомпетентними людьми. «В училищах, як тепер з'ясувалося, - писав в довідці-доповіді Е.А. Щаденко 20 березня 1940 г. - злочинно розтрачується навчальний час, тільки 66\% виділялося на навчання і необхідні види робіт, решту часу (127 днів в році) йшло на відсутність організованості, перерви, відпустки і свята» [11, с. 69].

Відсутність планової підготовки кадрів політичних працівників, а також необгрунтовані репресії привели до того, що до початку 1938 року в збройних силах не вистачало понад 10,5 тис. Осіб, що становило майже 30\% їх штатної чисельності. Некомплект політичних працівників старшого ланки становив близько 50\% від штату, а вищого - більше 50\%. Одночасно з 1934 р по 1939 р знизилася питома вага політпрацівників з вищою і середньою військово-політичним утворенням в два рази [12, с. 130].

За рішенням Політбюро ЦК ВКП (б), прийнятому в кінці грудня 1937 року, поряд з Політичним управлінням Робоча-Селянської Червоної Армії в складі Народного комісаріату РККФ створюється інший центральний військово-політичний орган Збройних Сил-політичних управління Робітничо-Селянського Червоного флоту, на правах військово-морського відділу ЦК ВКП (б). Його основою послужив морський відділ ПУРСЧА. Політичне управління РККФ складалося з відділів: керівних партійних органів, партійної пропаганди, агітації і друку, кадрів і постачання, а структура ПУРСЧА до 1939 року набуває нової налагоджену систему.

У початку 1938 року за рішенням ЦК ВКП (б) Військово-політичної академії було присвоєно ім'я В.І. Леніна і прийнято рішення про переведення в Москву. Одночасно вживалися заходи щодо поліпшення їі роботи, зміцненню викладацького складу. У 1938 р набір слухачів у Військово-політичну академію ім. В.І. Леніна в порівнянні з попереднім роком було збільшено в три рази [6, с. 247]. У цей рік було проведено прийом на курси викладачів, на які приймалися члени ВКП (б) викладач військових і військово-політичних училищ, інструктора пропаганди, партійно-політичні працівники РСЧА, а також комуністи цивільних парторганізацій у віці не старше 40 років.

У 1939 р з ініціативи ПУРСЧА була розширена мережа вечірнього і заочного факультетів при Військово-політичній академії ім. B.I. Леніна їх філій в Ленінграді, Києві і Смоленську [13, с. 169].

У 1938-1939 рр. створюється 6 нормальних військово-політичних училищ з дворічним терміном навчання та 18 окружних військово-політич- 
них училищ з річним терміном навчання. Створення нових навчальних закладів дозволило в короткий термін дати всім політрукам середнє військово-політичне утворення за скороченою програмою [6, с. 248].

Згідно з довідкою ПУРСЧА, кількість слухачів і курсантів, які навчаються у військово-політичних навчальних закладах і на курсах РСЧА на 5 березня 1939 року становило 11092 людини. 3 них 1396 осіб навчалося в Військово-політичної академії ім. B.I. Леніна, 3595 - в нормальних військово-політичних училищах, 1625 - в 16 окружних військово-політичних училищах, інші - на різних військово-політичних курсах.

Військово-політичні навчальні заклади складали за чисельністю майже 20\% всіх сухопутних військ. Поряд з розширенням старих і створенням нових середніх і вищих військово-навчальних закладів, утворюється широка мережа курсів перепідготовки. Крім раніше існуючих двох курсів з удосконалення політскладу, відкриваються нові курси для підготовки комісарів.

Зміст підготовки на курсах було визначено директивою ПУРСЧА № 8 від 7 січня 1939 р. У число обов'язкових предметів для вивчення в військово-політичних училищах входили: часу);

1) Історія СРСР (для її вивчення виділялося 100 годин навчального

2) Історія ВКП (б) (220 годин);

3) Партійно-політична робота в РСЧА (30 годин);

4) Методи боротьби зі шпигунсько-шкідницької, диверсійної і терористичної діяльністю розвідок капіталістичних країн і їх троцькістсько-бухаринской агентури (30 годин).

Головним недоліком курсової підготовки було, то, що вона була скороченою; предмети давалися в недостатньому обсязі; навчальний процес не був забезпечений необхідним інвентарем та літературою.

Наступним кроком, що дозволив збільшити чисельність політпрацівників і зміцнити кадри політскладу, стало введення інституту заступників і помічників політруків. Підбір та затвердження заступників і помічників політруків ЦК ВКП (б) поклав на військових комісарів та начальників політвідділів дивізій. На посади заступників політруків підбиралися найбільш політично грамотні, підготовлені для вступу в партію комсомольці, помічниками політруків висувалися менш підготовлені комсомольці. В подальшому по мірі політичного і військового зростання помічники призначалися заступниками політруків.

На початку квітня 1938 р. за пропозицією Головного військового ради ЦК ВКП (б) вирішив відібрати 5000 кращих заступників і помічників політруків, зарахувати їх в кадри і послати на курси молодших політруків. У 1939 р шестимісячні курси молодших політруків пройшло близько 9 тис. Заступників політруків.

11 січня 1939 року начальник Політичного управління РСЧА відправив у військові училища телеграму, в якій говорилося: «Всіх членів і кандидатів партії з числа випускаються лейтенантів і воентехніка затримати в училище до особливого розпорядження за винятком призначених на політроботу». Сенс цієї телеграми полягав в тому, щоб вирішити пробле- 
му укомплектованості штатів політпрацівників за рахунок випускників не політичних училищ.

Для підвищення прошарку комуністів в політорганам і вирішення проблеми укомплектованості армії політработниками 29 серпня 1939 р. Політбюро ЦК ВКП (б) видав постанову «Про відбір 4000 комуністів на політроботу в РСЧА», в якому пропонувалося провести призов кадрів політпрацівників запасу. Відібрані комуністи повинні були бути політично перевіреними, фізично здоровими, в якому віці старше 35 років для вищого політскладу, 30 - для старшого і 25 - для середнього політскладу, з утворенням в обсязі не нижче середньої школи [8, с. 287].

Всі ці заходи забезпечили значне збільшення кадрів політскладу. В середині 1940 року в Червоній Армії було понад 70 тис. Політпрацівників - майже в три рази більше, ніж в 1937 р Всього за два роки, в основному в 1938-1939 рр., Було призначено більше 41 тис. Політпрацівників. Однак, незважаючи на вжиті заходи повністю усунути некомплект політскладу в армії не вдалося. Серйозною проблемою залишалася кваліфікація політпрацівників, більшість з яких за рік по кілька разів висувалися на все більш відповідальні посади, не маючи достатнього досвіду роботи [13, с. 281].

Таким чином, в передвоєнні роки керівництво будівництвом політорганов носило суперечливий, непослідовний характер, поглиблюються проведеної в армії чищенням.

\section{СПИСОК ВИКОРИСТАНИХ ДЖЕРЕЛ}

1. Волков К.В. Советско-германские отношения во второй половине 1940 года. Вопросы истории. 1997. № 2. С. 3-17.

2. Красная звезда. 1937.14 июня.

3. XVIII съезд ВКП(б). Стенографический отчет. С. 274.

4. Комал Ф.Б. Военные кадры накануне войны. Военно-исторический журнал. 1990. № 2. С. 21-28.

5. Известия ЦК КПСС. 1990. № 3. С.190.

6. Петров Ю.П. Строительство политорганов, партийных и комсомольских организаций армии и флота (1918-1968 гг.). М.: Воениздат. 1968. 542 с.

7. Орлов П. Боевая программа теоретического вооружения военных кадров. Партийно-политическая работа в РККА. 1939. № 1. С. 27-36.

8. КПСС о Вооруженных Силах Советского Союза: Документы 19171981. М.: Воениздат, 1981. 622 с.

9. История Великой Отечественной войны Советского Союза. 19411945. В 6-ти т. Т. 1. Подготовка и развязывание войны империалистическими державами. М.: Воениздат, 1961. 538 с.

10. Комал Ф.Б. Военные кадры накануне войны. Военно-исторический журнал. 1990. № 2. С. 21-29.

11. Анфилов В.А. Дорога к трагедии сорок первого года. М., 1997. 304 с.

12. Тельпуховский Б.С. КПСС во главе строительства Вооруженных Сил СССР. Окт. 1917-1982 гг.: Исторический очерк. М.: Политиздат, 1983. $283 \mathrm{c}$.

13. Политорганы Советских Вооруженных Сил: Историко-теоретический очерк. М.: Воениздат, 1984. 400 с. 


\section{O. Severinova}

\section{MILITARY AND POLITICAL WORK WITH THE FORCES OF THE ARMED FORCES USSR IN THE PRE-WAR PERIOD}

The article is devoted to the study of the peculiarities of military-political work with the personnel of the armed forces of the USSR in the pre-war period. The article also analyzes the main directions and approaches of various scientists to study this issue. It was found that in order to develop the organizational structure and staffs of the central bodies of the People's Commissariat of Defense of the USSR, on the basis of the scheme approved by the People's Commissar for Defense, groups of five people were set up. A group headed by the Deputy Chief was appointed to work on the transformation of the Political Department of the Workers 'and Peasants' Red Army. After the end of this group, the political leadership received proposals to improve the management system of propaganda and optimize a number of staff categories. It was found that the increase in the number of the army again led to a shortage of political workers, weakened political work, especially among the rank and file, forced the country's leadership to make new organizational changes to overcome the threat, weaken the leadership of the Armed Forces, reduce party influence. In addition, due to the rapid deployment of the Armed Forces, the repression in the army, a large number ofyoung commanders, often did not have sufficient experience in leading troops, were promoted to senior positions. Many of them were non-partisan. Thus, the majority of the command staff in 1933 were quite young servicemen who did not accumulate the necessary experience of military leadership. The situation was seriously aggravated in the mid-second half of the 1930s. It was determined that the weak training of officers was due primarily to the insufficient level of knowledge acquired during training in military schools. The conditions of military educational institutions of that period were extremely difficult. Curricula in military academies and schools were often composed by incompetent people. Military-political educational institutions accounted for almost $20 \%$ of all ground forces. Along with the expansion of the old and the creation of new secondary and higher military educational institutions, a wide network of retraining courses is being formed. In addition to the two existing courses on improving the political staff, new courses are being opened to train commissioners.

Keywords: Armed forces, military-service relations, personnel, militarypolitical work. 